\title{
Efektifitas Penerapan Model Pembelajaran Predict Observe Explain untuk Melatih Keterampilan Berpikir Kritis Siswa SMA dengan Metode Library Research
}

\author{
Yuyun Nailul Qomariah", Z. A. Imam Supardi \\ Progam Studi Pendidikan Fisika, Jurusan Fisika, FMIPA, Universitas Negeri Surabaya \\ *Email: yuyun.17030184103@mhs.unesa.ac.id \\ DOI: https://doi.org/10.33369/pendipa.6.1.49-56
}

\begin{abstract}
[The Effectiveness Of Applying The Predict Observe Explain Learning Model To Train critical Thinking Skills Of High School Students Using The Library Research Method]. The aim of this study was to determine the effectiveness of application of the Predict Observe Explain (POE) model to train high school students' critical thinking skills. Thes type of the research was descriptive quantitative using the Library Research method. The type of data used was secondary data obtained from national and international journals. The steps used were writing the research objectives, looking for journals that are relevant to the research objectives, reading abstracts and all the contents of the journal. The data obtained wais in the form of quantitative data which was analyzed using the $N$-gain test and qualitative which was written into the review table. Based on research data of relevant journal, the average pretest and posttest scores were 34.31 and 62.05. The $N$-gain value was 0.52 with moderate classification. It can be concluded that the application of the POE learning model is effective for training high school students' critical thinking skills
\end{abstract}

Keywords: POE, Critical Thinking, High School Student, Library Research.

\begin{abstract}
ABSTRAK
Penelitian ini bertujuan untuk mengetahui efektifitas penerapan model Predict Observe Explain untuk melatih keterampilan berpikir kritis siswa SMA. Jenis penelitian ini merupakan kuantitatif deskriptif menggunakan metoda Library Research. Jenis data yang digunakan yaitu data sekunder yang diperoleh dari jurnal nasional dan internasional. Langkah yang digunakan dengan menuliskan tujuan penelitian, mencari jurnal yang relevan dengan tujuan penelitian, membaca abstrak dan seluruh isi jurnal. Data yang didapatkan berupa data kuantitatif yang dianalisis menggunakan uji N-gain dan data kualitatif yang dituliskan ke dalam tabel review. Berdasarakan data penelitian dari jurnal yang relevan didapatkan hasil rata - rata skor pretest dan posttest sebesar 34,31 dan 62,05. Nilai N-gain sebesar 0,52 dengan klasifikasi sedang. Dari penelitian ini dapat disimpulkan bahwa penerapan model pembelajaran POE efektif untuk melatih keterampilan berpikir kritis siswa SMA.
\end{abstract}

Kata kunci: POE, berpikir kritis, siswa SMA, Library Research.

\section{PENDAHULUAN}

Pendidikan adalah bentuk usaha untuk melatih potensi dan keterampilan seseorang sejak lahir. Ilmu Pengetahuan dan Teknologi menjadi penunjang dalam sistem pendidikan. Sistem pendidikan bertanggung jawab dalam meningkatkan keterampilan Sumber Daya
Manusia (SDM). Dalam dunia pekerjaan di abad ke 21 ini SDM dituntut untuk bisa berpikir tingkat tinggi yakni dengan berpikir secara kritis (critical thinking), dapat menyelesaikan masalah (problem solving), dan memiliki kemauan belajar sesuatu yang baru dan menciptakan hal baru.

Kurikulum 2013 diartikan bahwa proses pembelajaran harus difokuskan kepada 
pengembangan kompetensi peserta didik. Kompetensi yang dimaksud yaitu keterampilan memecahkan masalah, keterampilan berpikir tingkat tinggi, kemampuan melakukan penyelidikan ilmiah dengan mengimplementasikan pengetahuan dan membuat karya kreatif dan inovatif yang berhubungan dengan kehidupan sehari hari (Kemendikbud, 2018).

Fisika merupakan salah satu bidang pendidikan ilmu pengetahuan alam yang fokus terhadap kajian materi, energi dan hubungan keduanya. Kajian tersebut menghasilkan konsep fisika bersifat nyata dan abstrak (Nurbaiti et al., 2020). Konsep fisika yang abstrak membuat peserta didik beranggap bahwa fisika merupakan mata pelajaran yanng sulit dan di takuti (Sari \& Alarifin, 2016). Pembelajaran fisika harus diarahkan mencari informasi berupa fakta fakta dan melakukan eksperimen untuk menguji hipotesis dan menganalisis hasil eksperimen sehingga membantu peserta didik lebih memahami konsep. Pengalaman belajar yang berfokus pada peserta didik harus ditonjolkan dalam pembelajaran fisika (Yeritia et al., 2017). Pengalaman belajar yang sesuai dengan kurikulum 2013 yaitu dengan melakukan Scientific Approach (pendekatan ilmiah). Agar pelaksanaan pengalaman belajar dilakukan dengan baik peserta didik dituntut untuk menggunakan keterampilan berpikir kritis. Menurut Krathwohl \& Anderson (2010) keterampilan berpikir kritis meliputi tiga tingkat taksonomi Bloom (revisi) yaitu menganalisis (C4), mengevalusi (C5), dan mencipta (C6).

Dalam proses pembelajaran pemilihan model dan metode pembelajaran sangatlah penting. Proses pembelajaran yang menjadikan siswa sebagai tokoh utama dalam pembelajaran dapat melatih keterampilan berpikir kritis dan kepercayaan diri. Salah satu Model pembelajaran yang sesuai yaitu model pembelajaran Predict Observe Explain (POE). Dalam Model POE siswa siswa diarahkan untuk melakukan prediksi suatu fenomena, mengamati melalui eksperimen, dan menjelaskan kesesuaian prediksi dengan hasil pengamatan (Alfiyanti et al., 2020). Model POE memiliki tiga tahapan yaitu, memprediksi (Predict), mengamati (Observe) dan menjelaskan (Explain )(Hidayah \& Yuberti, 2018). Oleh karena itu pada penelitian ini bertujuan untuk mengkaji efektivitas penerapan model pembelajaran POE untuk melatih keterampilan berpikir siswa SMA.

\section{METODE PENELITIAN}

Penelitian ini menggunakan metoda studi kepustakaan (Library Research) . Sumber data dalam penelitian ini merupakan data sekunder yang diperoleh dengan mengumpulkan jurnal nasional dan internasional. Jenis penelitian ini merupakan penelitian kuantitatif deskriptif dengan mendeskripsikan data kuantitatif yang diperoleh dari jurnal nasional dan internasional. Pengumpulan data melalui proses studi pustaka yaitu menuliskan tujuan penelitian, yang kemudian mencari jurnal yang relevan dengan tujuan penelitian, membaca abstrak dan seluruh isi jurnal. Dengan membaca seluruh isi jurnal penelitian dan mendapatkan hasil penelitian dari jurnal tersebut (Suprapto et al., 2020).

Gambar 1. Teknik Pengumpulan Data

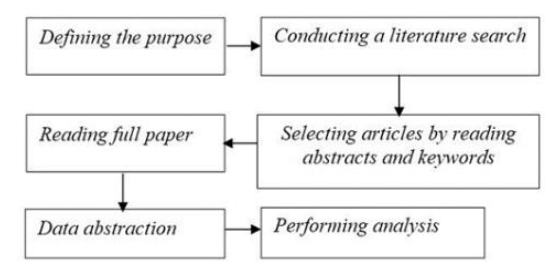

Data dalam penelitian ini berupa data kuantitatif dan kualitatif. Data dianalisis menggunakan uji $\mathrm{N}$-gain dan di deskripsikan sesuai dengan tujuan penelitian. Data kuantitatif yang diperoleh data skor Pretest dan Posttest setiap judul penlitian, dan nilai setiap indikator keterampilan berpikir kritis yang di persentasekan. Analisis uji N-gain digunakan untuk menganalisis rata - rata skor pretest dan posttest. Pada proses analisis Uji N-gain (Gain Ternormalisasi) peningkatan keterampilan berpikir kritis siswa dapat diketahui dan dibuktikan dengan Rata-rata Skor Pretest dan Posttest setiap judul penelitian. Untuk menemukan Uji $\mathrm{N}$-gain dapat menggunakan persamaan menurut Richard R.Hake (Fayakun \& Joko, 2015) :

$$
N-\text { gain }=\frac{\text { Skor Posttest }- \text { Skor Pretest }}{\text { Skor Ideal }- \text { Skor Pretest }}
$$


Dengan klasifikasi nilai N-gain menurut Richard R.Hake sebagai berikut :

Tabel 1. Klasifikasi N-gain menurut Richard Hake (Fayakun \& Joko, 2015)

\begin{tabular}{ll}
\hline Nilai N-gain & Klasifikasi \\
\hline $\mathbf{0 , 7 0}<\mathbf{N}$-gain $\leq \mathbf{1 , 0 0}$ & Tinggi \\
$\mathbf{0 , 3 0}<$ N-gain $\leq \mathbf{0 , 7 0}$ & Sedang \\
$\mathbf{N}$-gain $\leq \mathbf{0 , 3 0}$ & Rendah \\
\hline
\end{tabular}

Data kualitatif dituliskan kedalam tabel yang berisi tentanng asal jurnal/artikel, judul, penulis, hasil jurnal, dan analisis jurnal menurut penulis. Selanjutnya penarikan kesimpulan yaitu menuliskan jawaban dari tujuan penelitian.

\section{HASIL DAN PEMBAHASAN}

Pembelajaran di kelas merupakan proses peserta didik untuk mendapatkan ilmu pengetahuan, dengan adanya interaksi sosial antar satu sama lain dan pendidik dengan peserta didik. Kegiatan pembelajaran didalam kelas menggunakan model pembelajaran guna untuk menjembatani pendidik mentrasfer ilmu ke pada peserta didik. Pendidik harus sesuai dalam memilih model pembelajaran dengan mempertimbangkan beberapa faktor yakni materi yang akan dibahas, jumlah peserta didik, dan fasilitas yang ada disekitar. Pada Model POE peserta didik dituntut untuk menggali pengetahuan awalnya berdasarkan permasalahan yang diberikan dengan memberikan dugaan, membuktikan pengetahuan awalnya relevan dengan konsep permasalahan yang kemudian akan memunculkan sebuah pengetahuan baru berupa hasil eksperiman dan hasil analisa, peserta didik menjelaskan hasil pembuktian sudah sesuai dengan dugaan yang diberikan. Model POE memiliki peran dalam meningkatkan keterampilan berpikir kritis dengan menganalisis permasalahan.

Tabel 2. Rata - rata Skor Pretest, Posttest dan N-gain

\begin{tabular}{lccc}
\hline \multicolumn{1}{c}{ Artikel } & $\begin{array}{c}\text { Skor } \\
\text { Pretest }\end{array}$ & $\begin{array}{c}\text { Skor } \\
\text { Posttest }\end{array}$ & $\begin{array}{c}\text { N- } \\
\text { gain }\end{array}$ \\
\hline Judul : & & & \\
$\begin{array}{l}\text { Peningkatan } \\
\text { Kemampuan }\end{array}$ & 28 & 79 & 0,71 \\
\hline
\end{tabular}

\begin{tabular}{llcc}
\hline \multicolumn{1}{c}{ Artikel } & $\begin{array}{c}\text { Skor } \\
\text { Pretest }\end{array}$ & $\begin{array}{c}\text { Skor } \\
\text { Posttest }\end{array}$ & $\begin{array}{c}\text { N- } \\
\text { gain }\end{array}$ \\
\hline Berpikir Kritis & & & \\
Peserta Didik & & & \\
Melalui & & \\
Implementasi & & \\
Lembar Kerja & & \\
Peserta Didik & & \\
Berbasis Predict & & \\
Observe Explain & & \\
Penulis : & & \\
Mulyani et al., \\
(2018)
\end{tabular}

\section{Judul:}

Efektivitas

Pembelajaran Fisika

Menggunakan

Pembelajaran Fisika

Menggunakan

Model Kontekstual

(CTL) Dengan

Metode Predict,

$9,059 \quad 17,56 \quad 0,37$

Observe, Explain

Terhadap

kemampuan Berpikir

Tingkat Tinggi

Penulis:

Fayakun \& Joko, (2015)

\section{Judul:}

Pengaruh Model

POE Terhadap Hasil

Belajar Kognitif dan $\quad 57,97 \quad 79,3 \quad 0,51$

Berpikir kritis siswa

Penulis:

Dewi et al., (2019)

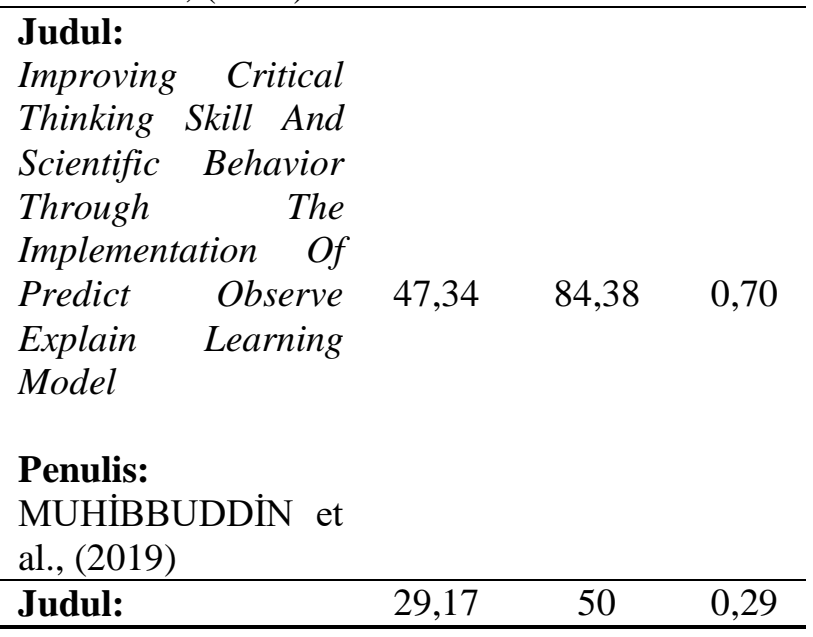




\begin{tabular}{cccc}
\hline Artikel & $\begin{array}{c}\text { Skor } \\
\text { Pretest }\end{array}$ & $\begin{array}{c}\text { Skor } \\
\text { Posttest }\end{array}$ & $\begin{array}{c}\mathrm{N}- \\
\text { gain }\end{array}$ \\
\hline
\end{tabular}

The Effect of Predict

- Observe - Explain

(POE) Strategy on

Students'

Conceptual Mastery

and Critical

Thinking in Learning

Vibration and Wave

Penulis:

Furqani et al., (2018)

\begin{tabular}{llll}
\hline Rata-rata & 34,31 & 62,05 & 0,52 \\
\hline
\end{tabular}

Berdasarkan tabel 2 didapatkan hasil rata rata pretest dan posttest setiap judul, dengan rata - rata pretest sebesar 34,31 dan postttest sebesar 62,05. Dan Nilai rata - rata N-gain masuk kedalam klasifikasi sedang sebesar 0,52. Pada hasil penelitian tersebut dapat diketahui bahwa terjadi peningkatan kemampuan berpikir kritis peserta didik setelah diberi perilaku penerapan model pembelajaran Predict Observe Explain .

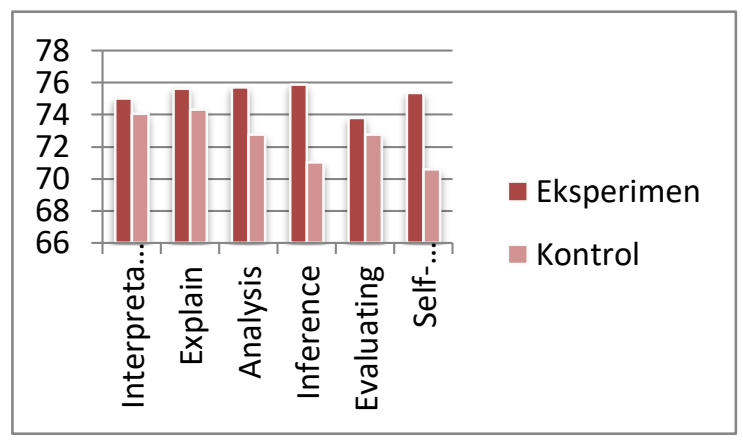

Gambar 2. Grafik Perbandingan Persentase

Rata-rata Skor Aspek Keterampilan Berpikir Kritis di Kelas Kontrol dan Eksperimen

(MUHIBBUDDIN et al., 2019)

Berdasarkan Grafik diatas terdapat lima indikator keterampilan berpikir kritis yaitu Explanation, Analysis, Interpretation, Inference dan Evaluation. Pada kelas eksperimen diberi perilaku dengan diterapkannya model POE yang menunjukkan skor dsetiap Indikator lebih tinggi daripada kelas kontrol. Sehingga penerapan Model pembelajaran POE lebih efektif untuk meningkatkan keterampilan berpikir kritis siswa. Dalam menyelesaikan permasalahan fisika tidak semuanya dapat diselesaikan dengan persamaan, tetapi juga membutuhkan keterampilan berpikir kritis (Winarti, 2015).

Berikut ini tabel analisis pengaruh penerapan model POE terhadap peningkatan keterampilan berpikir kritis.

Tabel 3. Analisis Pegaruh Penerapan Model POE terhadap peningkatan keterampilan berpikir kritis siswa SMA

\begin{tabular}{|c|c|c|}
\hline No & & \\
\hline 1 & $\begin{array}{l}\text { Judul: } \\
\text { The Effectiveness of } \\
\text { Predict Observe } \\
\text { Explain (POE) } \\
\text { Model with PhET to } \\
\text { Improve Critical } \\
\text { Thinking Skills of } \\
\text { Senior High School } \\
\text { Students } \\
\text { Penulis: } \\
\text { Alfiyanti et al., } \\
\text { (2020) } \\
\text { Hasil Jurnal: } \\
\text { Penerapan model } \\
\text { pembelajaran } \\
\text { menggunakan model } \\
\text { POE dengan media } \\
\text { PhET dapat } \\
\text { meningkatkan } \\
\text { keterampilan berpikir } \\
\text { kritis siswa SMA. }\end{array}$ & $\begin{array}{l}\text { Model } \\
\text { pembelajaran POE } \\
\text { pada materi yang } \\
\text { dipadukan dengan } \\
\text { menggunakan } \\
\text { media Phet efektif } \\
\text { untuk } \\
\text { meningkatkan } \\
\text { keterampilan } \\
\text { berpikir kritis siswa } \\
\text { SMA pada konsep } \\
\text { fisika yang ditinjau } \\
\text { dari ketercapaian } \\
\text { indicator } \\
\text { keterampilan } \\
\text { berpikir kritis yaitu } \\
\text { berupa } \\
\text { menjelaskan, } \\
\text { menganalisis, } \\
\text { menginterpretasika } \\
\text { n, menginterferensi } \\
\text { dan mengevaluasi }\end{array}$ \\
\hline 2 & 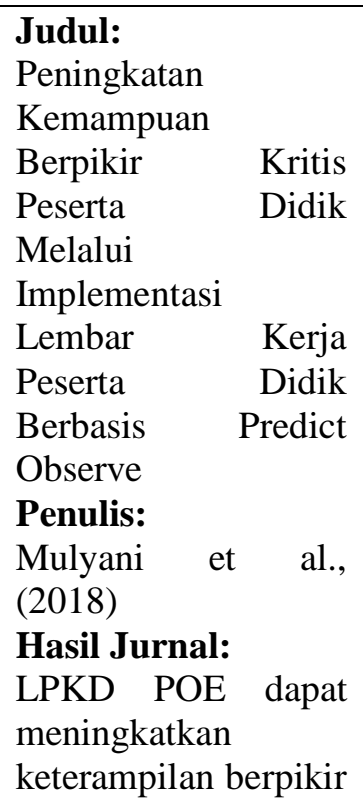 & $\begin{array}{l}\text { Pembelajaran } \\
\text { Fisika } \\
\text { menggunakan } \\
\text { LKPD POE dapat } \\
\text { membantu siswa } \\
\text { dalam membangun } \\
\text { pemikiran untuk } \\
\text { menganalisis dan } \\
\text { mengevaluasi } \\
\text { permasalahan } \\
\text { konsep } \\
\text { fisika.Peserta didik } \\
\text { dikatakan mampu } \\
\text { berpikir kritis, jika } \\
\text { peserta didik } \\
\text { menguasai } \\
\text { kemampuan } \\
\text { menganalisis dan }\end{array}$ \\
\hline
\end{tabular}




\begin{tabular}{|c|c|c|}
\hline No & Artikel & Hasil Review \\
\hline & $\begin{array}{lr}\text { kritis peserta } & \text { didik } \\
\text { ditinjau } & \text { dari } \\
\text { menganalisis } & \text { dan } \\
\text { mengevaluasi. } & \\
\end{array}$ & mengevaluasi. \\
\hline 3 & 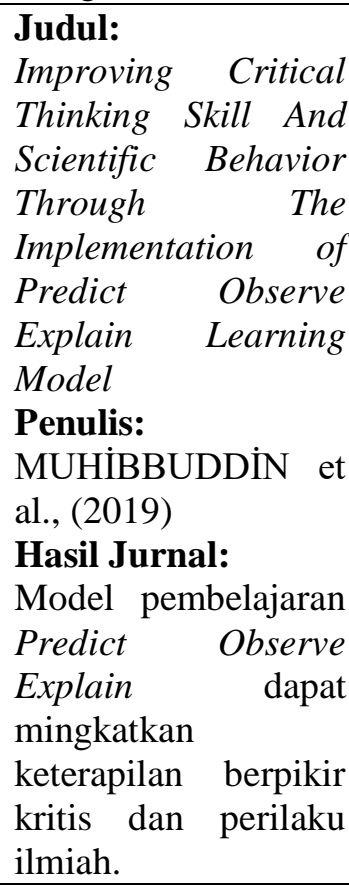 & \begin{tabular}{l}
\multicolumn{2}{l}{ Meningkatnya } \\
Keterampilan \\
berpikir kritis \\
ditinjau dari \\
terpenuhinya enam \\
aspek \\
Menafsirkan yaitu \\
(Interpretation), \\
Menjelaskan \\
(explain), \\
menganalisis \\
(analyse), \\
menyimpulkan \\
(Interference), \\
mengevaluasi \\
(evaluation) dan \\
regulasi diri (self \\
regulation)
\end{tabular} \\
\hline 4 & 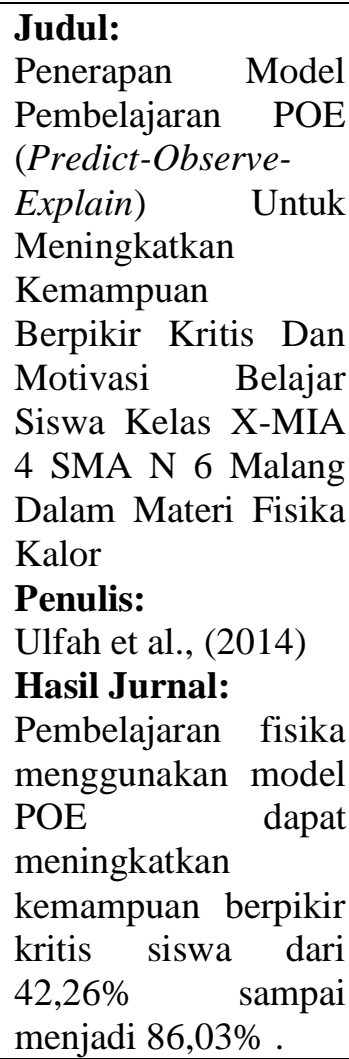 & $\begin{array}{lr}\text { Model } & \text { POE } \\
\text { diterapkan } & \text { pada } \\
\text { materi } & \text { kalor, } \\
\text { pembelajaran } & \\
\text { dilakukan dalam } \\
\text { empat } \\
\text { pertemuan di setiap } \\
\text { pertemuannya } \\
\text { mengalami } \\
\text { peningkatan } \\
\text { presentase } \\
\text { kemampuan } \\
\text { berpikir kritis }\end{array}$ \\
\hline 5 & Judul: & Kemampuan \\
\hline
\end{tabular}

\begin{tabular}{|c|c|c|}
\hline No & Artikel & Hasil Review \\
\hline & $\begin{array}{l}\text { Pengaruh Model } \\
\text { Pembelajaran } \\
\text { Predict-Observe- } \\
\text { Explain (POE) } \\
\text { Berbantuan Simulasi } \\
\text { Virtual Terhadap } \\
\text { Penguasaan Konsep } \\
\text { Fisika Siswa SMA } \\
\text { Penulis: } \\
\text { Nurbaiti et al., } \\
\text { (2020) } \\
\text { Hasil Jurnal: } \\
\text { Penguasaan konsep } \\
\text { fisika mengalami } \\
\text { peningkatan dengan } \\
\text { diterapkannya } \\
\text { pembelajaran } \\
\text { menggunakan model } \\
\text { POE yang dipadukan } \\
\text { dengan simulasi } \\
\text { virtual PhET. }\end{array}$ & $\begin{array}{l}\text { kognitif siswa pada } \\
\text { materi fisika } \\
\text { meningkat dan } \\
\text { siswa berperan } \\
\text { aktif dalam } \\
\text { pembelajaran } \\
\text { dengan } \\
\text { diterapkannya } \\
\text { model POE. }\end{array}$ \\
\hline 6 & 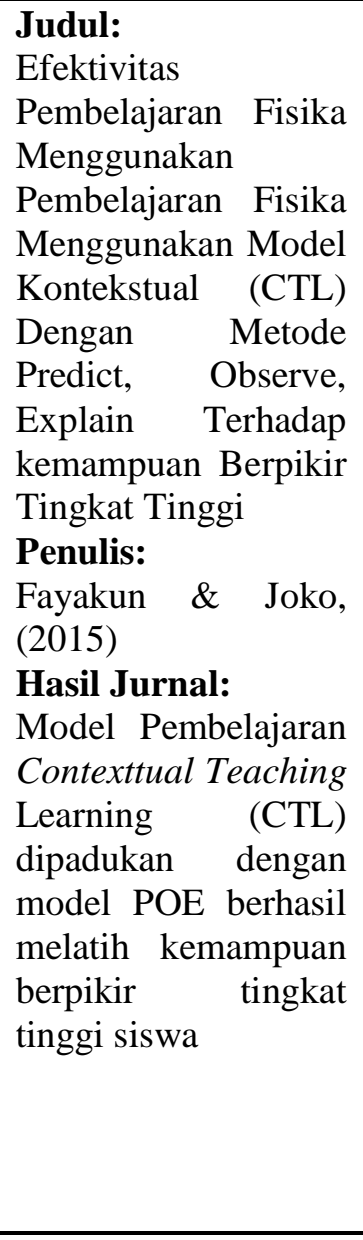 & $\begin{array}{l}\text { Model POE } \\
\text { diterapkan dalam } \\
\text { langkah } \\
\text { pembelajaran } \\
\text { inquiry pada model } \\
\text { pembelajaran CTL } \\
\text { dengan melakukan } \\
\text { praktikum. Siswa } \\
\text { memprediksi } \\
\text { sebuah fenomena, } \\
\text { merancang dan } \\
\text { mengobservasi } \\
\text { percobaan dan } \\
\text { menganalisis data. } \\
\text { High Order } \\
\text { Thinking (berpikir } \\
\text { tingkat tinggi) } \\
\text { siswa ditinjau dari } \\
\text { cara siswa } \\
\text { menjawab soal } \\
\text { dengan membuat } \\
\text { hipotesis terhadap } \\
\text { permasalahan yang } \\
\text { ada pada soal, } \\
\text { menjawab hipotesis } \\
\text { dengan san } \\
\text { menganalisa } \\
\text { perhitungan soal, }\end{array}$ \\
\hline
\end{tabular}




\begin{tabular}{|c|c|c|c|c|c|}
\hline No & Artikel & Hasil Review & No & Artikel & Hasil Review \\
\hline & & $\begin{array}{l}\text { dan memberikan } \\
\text { alasan untuk } \\
\text { mendukung } \\
\text { hipotesis } \\
\text { menggunakan hasil } \\
\text { analisa yang siswa } \\
\text { peroleh. }\end{array}$ & & $\begin{array}{lr}\text { metode } & \text { Eksperimen } \\
\text { Ditinjau } & \text { dari } \\
\text { Pemahaman } & \text { Konsep } \\
\text { Fisika } & \\
\text { Penulis: } & \\
\text { Fitriana \& } & \text { Yuberti, } \\
(2019) & \end{array}$ & $\begin{array}{l}\text { utama. Siswa } \\
\text { mengekplorasi } \\
\text { gagasan dan } \\
\text { membuat hipotesis } \\
\text { atas permasalahan } \\
\text { yang diberikan, } \\
\text { melakukan }\end{array}$ \\
\hline 7 & $\begin{array}{l}\text { Judul: } \\
\text { Pengaruh } \\
\text { Penggunaan } \\
\text { berbasis } \quad \text { LKS } \\
\text { (Predict, Observe, } \\
\text { Explain) Terhadap } \\
\text { Hasil Belajar dan } \\
\text { Keterampilan } \\
\text { Berpikir Kritis } \\
\end{array}$ & $\begin{array}{l}\text { Keterampilan } \\
\text { berpikir kritis siswa } \\
\text { meningkat dengan } \\
\text { diterapkannya } \\
\text { Metode POE pada } \\
\text { LKS dalam } \\
\text { pembelajaran } \\
\text { fisika, dengan } \\
\text { memprediksi }\end{array}$ & & $\begin{array}{l}\text { Hasil Jurnal: } \\
\text { Pembelajaran fisika } \\
\text { menggunakan model } \\
\text { POE yang dipadukan } \\
\text { dengan metode } \\
\text { eksperimen dapat } \\
\text { meningkatkan } \\
\text { pemahaman konsep } \\
\text { fisika }\end{array}$ & $\begin{array}{l}\text { eksperimen untuk } \\
\text { mendapatkan data } \\
\text { dan menjelaskan } \\
\text { hasil ekperimen } \\
\text { untuk menjawab } \\
\text { hipotesis. }\end{array}$ \\
\hline & $\begin{array}{l}\text { SMA } \\
\text { Penulis: } \\
\text { Istiqomah et al., } \\
\text { (2015) } \\
\text { Hasil Jurnal: } \\
\text { Penerapan metode } \\
\text { POE pada LKS dapat } \\
\text { meningkatkan } \\
\text { keterampilan berpikir } \\
\text { kritis siswa }\end{array}$ & $\begin{array}{l}\text { hipotesis yang } \\
\text { ditentukan, } \\
\text { mengobservasi } \\
\text { dengan melakukan } \\
\text { eksperimen } \\
\text { sederhana untuk } \\
\text { memperoleh data, } \\
\text { dan menjelaskan } \\
\text { hasil eksperimen }\end{array}$ & 10 & $\begin{array}{l}\text { Judul: } \\
\text { The Impact of } \\
\text { Predict Observe } \\
\text { Explain } \quad \text { (POE) } \\
\text { strategy against } \\
\text { student's critical } \\
\text { thinking ability } \\
\text { Penulis: } \\
\text { Amirullah et al., } \\
(2019)\end{array}$ & $\begin{array}{l}\text { Pembelajaran } \mathrm{POE} \\
\text { dapat } \\
\text { meningkatkan } \\
\text { keterampilan } \\
\text { berpikir kritis siswa } \\
\text { ditinjau dari enam } \\
\text { indikator yaitu } \\
\text { memberikan } \\
\text { argumen, } \\
\text { merumuskan }\end{array}$ \\
\hline 8 & $\begin{array}{l}\text { Judul: } \\
\text { Pengaruh Model } \\
\text { Pembelajaran POE } \\
\text { (Predict-Observe- } \\
\text { Explain) Terhadap } \\
\text { Pemahaman Konsep } \\
\text { Fisika Ditinjau dari } \\
\text { Gaya Belajar Siswa }\end{array}$ & $\begin{array}{l}\text { Model POE } \\
\text { membantu siswa } \\
\text { untuk membuktikan } \\
\text { konsep berdasarkan } \\
\text { penulusuran yang } \\
\text { telah dilakukan } \\
\text { siswa. }\end{array}$ & & $\begin{array}{l}\text { Hasil Jurnal: } \\
\text { Strategi } \\
\text { Pembelajaran POE } \\
\text { dapat meningkatkan } \\
\text { keterampilan berpikir } \\
\text { kritis siswa }\end{array}$ & $\begin{array}{l}\text { masalah, } \\
\text { mengambil } \\
\text { keputusan dan } \\
\text { tindakan, } \\
\text { melakukan induksi, } \\
\text { melakukan deduksi } \\
\text { dan melakukan } \\
\text { evaluasi }\end{array}$ \\
\hline
\end{tabular}

Penulis:

Restami (2019)

Hasil Jurnal:

Pembelajaran fisika menggunakan model pembelajaran POE dapat meningkatkan pemahaman konsep fisika.

\begin{tabular}{llll}
\hline 9 & Judul: & & \multicolumn{2}{l}{ Pemahaman konsep } \\
& Pembelajaran & Fisika & siswa mengalami \\
Berbasis & POE & peningkatan karena \\
& (Predict-Observe- & padar proses \\
& Explain) & pembelajaran siswa \\
Menggunakan & sebagai pelaku \\
\hline
\end{tabular}

Berdasarkan tabel penelitian dari data yang relevan, model pembelajaran Predict Observe Explain (POE) dapat meningkatkan keterampilan berpikir kritis siswa SMA. Hal tersebut terjadi karena peserta didik sebagai pelaku utama dalam pembelajaran. Sehingga peserta didik dituntut untuk menemukan konsep, mengolah dan menganalisis data berdasarkan pemikiran sendiri (Rosdianto et al., 2017).

Berdasarkan kajian data penelitian terdapat beberapa indikator keberhasilan siswa dalam menguasai keterampilan berpikir kritis yakni kemampuan menjelaskan (Explain), menganalisis (Analyse), menginterpretasi 
(Interpretation), menginterferensi (Interference) dan mengevaluasi (Evaluation).

Strategi pembelajaran POE terdapat tiga tahapan (Suyono \& Hariyanto, 2015) yakni yang pertama peserta didik dituntut untuk mebuat hipotesis yang didasari oleh fenomena atau permasalahan yang diberikan menggunakan gaya pemikiran sendiri. Tahapan selanjutnya peserta didik melakukan pengamatan atau percobaan yang sesuai dengan permasalahan. Yang terkhir peserta didik menjelaskan hasil penelitian dalam bentuk tesk dan secara verbal didepan kelas secara individu atau kelompok. Serta dibuktikannya kesesuaian atau ketidaksesuaiannya hasil penelitian dengan hipoteseis. Model POE dapat dipadukan dengan penggunaan media konvensional di laboratorium ataupun virtual seperti Phet.

\section{KESIMPULAN}

Berdasarkan data penelitian yang didapatkan, nilai rata-rata pretest sebesar 34,31 dan posttest sebesar 62,05, dengan nilai uji $\mathrm{N}$ gain sebesar 0,52 yang termasuk dalam klasifikasi sedang, sehingga posttest memiliki nilai yang lebih tinggi daripada pretest. Kami menyimpulkan bahwa proses pembelajaran yang menggunakan model POE efektif untuk melatih keterampilan berpikir kritis siswa SMA.

\section{DAFTAR PUSTAKA}

Alfiyanti, I. F., Jatmiko, B., \& Wasis. (2020). The Effectiveness of Predict Observe Explain (POE) Model with PhET to Improve Critical Thinking Skills of Senior High School Students. Studies in Learning and Teaching, 1(2), 76-85. https://doi.org/10.46627/silet.v1i2.34

Amirullah, G., Suciati, R., \& Handayani, D. (2019). The Impact of Predict Observe Explain ( POE ) strategy against student' $\mathrm{s}$ critical thinking ability Pengaruh Strategi Predict Observe Explain ( POE ) Terhadap Kemampuan Berpikir Kritis Siswa. Jurnal Ilmiah Pendidikan Biologi, 5(2), 173-180.

Dewi, A. F., Munandar, K., Prafitasari, A. N., Studi, P., Biologi, P., \& Muhammadiyah, U. (2019). PENGARUH MODEL POE TERHADAP HASIL BELAJAR KOGNITIF DAN BERFIKIR KRITIS SISWA THE
EFFECT OF POE MODELS ON THE RESULTS OF. 1-9.

Fayakun, M., \& Joko, P. (2015). Efektivitas Pembelajaran Fisika Menggunakan Model Kontekstual (Ctl) Dengan Metodepredict, Observe, Explain Terhadap Kemampuan Berpikir Tingkat Tinggi. Jurnal Pendidikan Fisika Indonesia, 11(1), 49-58. https://doi.org/10.15294/jpfi.v11i1.4003

Fitriana, A. W., \& Yuberti, Y. (2019). Pembelajaran Fisika Berbasis PEO (Predict-Observe-Explain) Menggunakan Metode Eksperimen Ditinjau dari Pemahaman Konsep Fisika. Indonesian Journal of Science and Mathematics Education, 2(2), 254-261. https://doi.org/10.24042/ijsme.v2i2.4350

Furqani, D., Feranie, S., \& Winarno, N. (2018). The Effect of Predict-Observe-Explain (POE) Strategy on Students' Conceptual Mastery and Critical Thinking in Learning Vibration and Wave. Journal of Science Learning, 2(1), https://doi.org/10.17509/jsl.v2i1.12879

Hidayah, A., \& Yuberti. (2018). Pengaruh Model Pembelajaran Poe (Predict-ObserveExplain) Terhadap Keterampilan Proses Belajar Fisika Siswa Pokok Bahasan Suhu Dan Kalor. Indonesian Journal of Science and Mathematics Education, 1(1), 21-27. http://ejournal.radenintan.ac.id/index.php/IJ SME/article/view/2470

Istiqomah, N., Supriadi, B., \& Nuraini, L. (2015). Analisis Hasil Belajar Siswa Melalui Pembelajaran Menggunakan Lks Berbasis Poe ( Predict, Observe, Explain ) Berbantu Phet Simulation. Jurnal Pembelajaran Fisika, 8(4), 248-256.

Kemendikbud. (2018). Permendikbud NO.36 Tahun 2018 tentang Perubahan Atas Permendikbud No.59 Tahun 2014 Tentang Kurikulum 2013 Sekolah Menengah/ Madrasah Aliyah.

Krathwohl, D. R., \& Anderson, L. W. (2010). Kerangka Landasan untuk Pembelajaran, Pengajaran dan Asesmen (Revisi taksonomi Pendidikan Bloom). Pustaka Belajar.

MUHIBBUDDİN, M., ILYAS, S., \& SAMYA, C. E. P. (2019). Improving Critical Thinking Skill and Scientific Behavior Through the Implementation of Predict 
Observe Explain Learning Model. IJAEDUInternational E-Journal of Advances in Education, 5(15), 337-342. https://doi.org/10.18768/ijaedu.593881

Mulyani, R., Saminan, S., \& Sulastri, S. (2018). Peningkatan Kemampuan Berpikir Kritis Peserta Didik Melalui Implementasi Lembar Kerja Peserta Didik Berbasis Predict Observe Explain. Jurnal Pendidikan Sains Indonesia, 5(2), 19-24. https://doi.org/10.24815/jpsi.v5i2.9810

Nurbaiti, N., Kosim, K., \& Taufik, M. (2020). Pengaruh Model Pembelajaran PredictObserve-Explain (POE) Berbantuan Simulasi Virtual Terhadap Penguasaan Konsep Fisika Siswa SMA. Jurnal Pendidikan Fisika Dan Teknologi, 6(1), 146. https://doi.org/10.29303/jpft.v6i1.1456

Restami, M. P. (2019). Pengaruh Model Pembelajaran POE (PREDICT-OBSERVEEXPLAIN) Terhadap Pemahaman Konsep Fisika Ditinjau dari Gaya Belajar Siswa. Jurnal Pendidikan Teknologi Dan Kejuruan, $\quad 16(1), \quad 11$. https://doi.org/10.23887/jptkundiksha.v16i1.16673

Rosdianto, H., Murdani, E., \& . H. (2017). the Implementation of Poe (Predict Observe Explain) Model To Improve Student'S Concept Understanding on Newton'S Law. Jurnal Pendidikan Fisika, 6(1), 55. https://doi.org/10.22611/jpf.v6i1.6899
Suprapto, N., Sunarti, T., Suliyanah, Wulandari, D., Hidayaatullaah, H. N., Adam, A. S., \& Mubarok, H. (2020). A systematic review of photovoice as participatory action research strategies. International Journal of Evaluation and Research in Education, 9(3), 675-683. https://doi.org/10.11591/ijere.v9i3.20581

Suyono, \& Hariyanto. (2015). Implementasi Belajar dan Pembelajaran. PT Remaja Rosdakarya.

Ulfah, Q. ., Asim, \& Parno. (2014). Penerapan Model Pembelajaran POE (PredictObserve-Explain) Untuk Meningkatkan Kemampuan Berpikir ritis Dan Motivasi Belajar Siswa Kelas X-MIA 4 SMA N 6 Malang Dalam Materi Fisika Kalor. Journal Pendidikan Fisika Universitas Negeri Malang, III.

Winarti. (2015). Profil Kemampuan Berpikir Analisis Dan Evaluasi Mahasiswadalam Mengerjakan Soal Konsep Kalor. Jurnal Inovasi Dan Pembelajaran Fisika, 2(1), 19-24. https://doi.org/10.36706/jipf.v2i1.2350

Yeritia, S., Wahyudi, W., \& Rahayu, S. (2017). Pengaruh Model Pembelajaran Inkuiri Terbimbing Terhadap Penguasaan Konsep Dan Kemampuan Berpikir Kritis Fisika Peserta Didik Kelas X Sman 1 Kuripan Tahun Ajaran 2017/2018. Jurnal Pendidikan Fisika Dan Teknologi, 3(2), 181. https://doi.org/10.29303/jpft.v3i2.398 